\title{
First occurrence of Cloudina carinata Cortijo et al., 2010 in South America, Tamengo Formation, Corumbá Group, upper Ediacaran of Midwestern
}

\author{
Primera cita de Cloudina carinata Cortijo et al., 2010 en \\ Sudamérica, Formación de Tamengo, Grupo de Corumbá, \\ Brasil Brazil
}

\author{
R.R. Adôrno ${ }^{1,2}$, D.H.G. Walde ${ }^{1}$, B.D. Erdtmann ${ }^{3}$, M. Denezine ${ }^{1}$, I. Cortijo ${ }^{4}$, D.A. Do Carmo ${ }^{1}$, \\ M. Giorgioni ${ }^{1}$, M.E.A.F. Ramos ${ }^{1}$, G. Fazio ${ }^{1}$ \\ ${ }^{1}$ University of Brasília, Institute of Geosciences, Campus Darcy Ribeiro, DF 70.910-900 Brasília, Brazil. Email: rodrigo. \\ adorno@cprm.gov.br; ORCID ID: https://orcid.org/0000-0003-1781-0694, http://orcid.org/0000-0001-5324-5480, http:// \\ orcid.org/0000-0003-4629-0907, http://orcid.org/0000-0002-1613-7242, http://orcid.org/0000-0003-0565-3150, http://orcid. \\ org/0000-0002-1741-3210, http://orcid.org/0000-0003-3325-5096 \\ ${ }^{2}$ Geological Survey of Brazil - Center for Technological Development-CEDES Setor Bancário Norte, DF 70040-904 Brasília, Brazil. \\ ${ }^{3}$ Freie Universität Berlin (FUB). Kaiserswerther Street 16-18, 14195 Berlin, Germany. https://orcid.org/0000-0002-0136-7854 \\ ${ }^{4}$ Área de Paleontología, Facultad de Ciencias, Universidad de Extremadura, Avenida de Elvas s/n, 06071 Badajoz, España. \\ http://orcid.org/0000-0002-6027-9002
}

\section{ABSTRACT}

It is herein presented the unprecedented occurrence of Cloudina carinata Cortijo et al., 2010 in the American continent. This new occurrence expanded the geographic distribution of this species, until now reported from sections in Spain and Siberia. The assembled biomineralizing metazoans Cloudina carinata, Cloudina lucianoi (Beurlen \& Sommer, 1957) and Corumbella werneri Hahn et al., 1982 are presented for the first time from the Tamengo Formation, Corumbá Group, Porto Figueiras section, Corumbá Municipality, Mato Grosso do Sul State, Brazil. This new occurrence could be employed as an additional biostratigraphic tool for international correlation of the terminal Ediacaran, as well as for palaeobiogeographic and palaeoecologic reconstructions.

Keywords: Cloudina carinata; terminal Ediacaran; Tamengo Formation; Brazil.

\section{RESUMEN}

Se documenta en este resumen la primera aparición de Cloudina carinata Cortijo et al., 2010 en el continente americano. Esta nueva aparición extiende la distribución geográfica de esta especie, hasta ahora restringida a España y Siberia. Se presenta por primera vez en la Formación de Tamengo (Corumbá, Estado de Mato Grosso do Sul, Brasil) la asociación de metazoos mineralizados compuesta por Cloudina carinata, Cloudina lucianoi

Recibido el 2 de mayo de 2019; Aceptado el 1 de julio de 2019; Publicado online el 12 de noviembre de 2019

Citation / Cómo citar este artículo: Adôrno, R.R. et al. (2019). First occurrence of Cloudina carinata Cortijo et al., 2010 in South America, Tamengo Formation, Corumbá Group, upper Ediacaran of Midwestern. Estudios Geológicos 75(2): e095. https://doi. org/10.3989/egeol.43587.550.

Copyright: () 2019 CSIC. This is an open-access article distributed under the terms of the Creative Commons Attribution-Non Commercial (by-nc) Spain 4.0 License. 
(Beurlen \& Sommer, 1957) y Corumbella werneri Hahn et al., 1982. Esta asociación podría ser útil como marcador bioestratigráfico en las correlaciones internacionales del Ediacárico terminal, así como para futuras reconstrucciones paleobiogeográficas y paleoecológicas.

Palabras clave: Cloudina carinata; Ediacárico terminal; Formación de Tamengo; Brasil.

\section{Introduction}

This work deals with the unprecedented occurrence of Cloudina carinata Cortijo et al., 2010 in the American continent. C. carinata had documented occurrences in Spain (Cortino et al., 2010, 2015) and Siberia, Russia (Kontorovich et al., 2008), and now a new occurrence from the Tamengo Formation at Porto Figueiras section, Corumbá Municipality, Mato Grosso do Sul State, Brazil is presented.

Cloudina species have wide geographic distribution reported from Namibia (Grant, 1990), Oman (Conway Morris et al., 1990), South China (Hua et al., 2005; Cai et al., 2013; Cortijo et al., 2015), Spain (Cortijo et al., 2010, 2015), Siberia (Terleev et al., 2011; Kontorovich et al., 2008); Mexico (SourTovar et al., 2007), Brazil (Adôrno et al., 2017), Argentina and Uruguay (Gaucher et al., 2006), Canada (Hofmann \& Mountjoy, 2001), Paraguay (Warren et al., 2011, 2013, 2014, 2017, 2019) and the USA (Grant, 1990; Zhuravlev et al., 2012).

Cloudina carinata occurs in the uppermost Ediacaran section of Spain, in association with C. lucianoi (Beurlen \& Sommer, 1957) in the Membrillar olistostrome (Cortijo et al., 2010) and the Navalpino Anticline, central Spain (Cortijo et al., 2015). Occurrences of Cloudina carinata and C. lucianoi have also been reported from Siberia, Russia (Terleev et al., 2011), and now it is herein presented the first occurrence of this species in South America from the yellowish siltstones of the Tamengo Formation.

\section{Results}

A new occurrence of Cloudina carinata is presented herein, in the Porto Filgueiras section, outcropping along the Paraguay river bank in a locality nowadays called Marina do Gelson, at the geographic coordinates: $-18.998748^{\circ} \mathrm{S}$ and $-57.629023^{\circ} \mathrm{W}$, approximately $750 \mathrm{~m}$ to the west of the Sobramil Port section. At this locality, C. carinata occurs in association with C. lucianoi and Corumbella werneri. The implication of this new occurrence of C. carinata in the Tamengo Formation is discussed herein under the light of its contribution to the palaeobiogeographic distribution of Cloudina species, the palaeogeography of Western Gondwana, the palaeoecology and the chronobiostratigraphy of the uppermost Ediaracan sections.

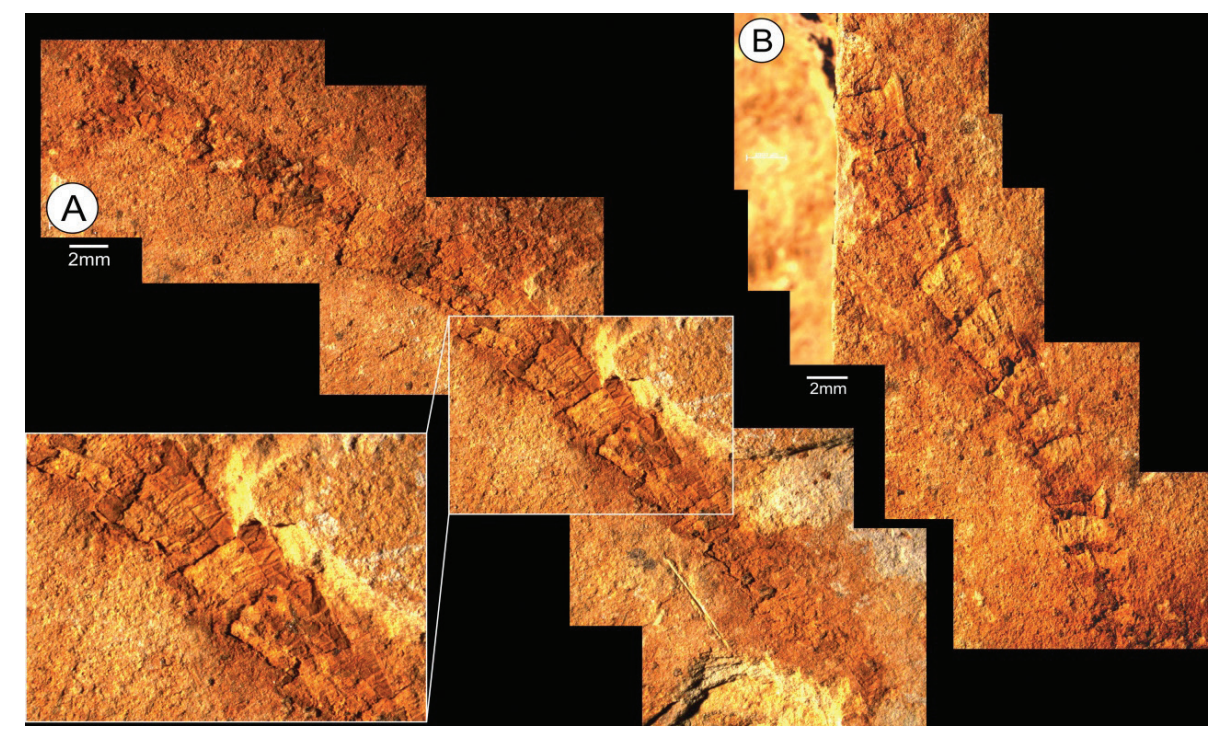

Figure 1.-Two specimens of Cloudina carinata Cortijo et al., 2010 from the Tamengo Formation Specimen MAF-522 (original number MP-717). 
The study material consists of silty impression moulds of the exterior wall of Cloudina carinata (Fig. 1). The taxonomic assignment of C.carinata from the Tamengo Formation is the result of morphometric and morphologic analysis. Regarding the mode of occurrence, $C$. carinata and Corumbella werneri occur in pelitic layers of the Tamengo Formation, while C. lucianoi occurs in carbonate rocks. This could reflect, to a certain extent, that C.lucianoi preferred palaeoecological conditions with clear waters and without major siliciclastic input, where carbonate could precipitate, whereas C. carinata and Corumbella werneri dwelled in probably deeper and calmer conditions, with more detrital influx. The occurrence of Cloudina carinata in the Tamengo Formation increases the potential for the inclusion of the Tamengo Formation in the international biostratigraphic correlation.

\section{Conclusions}

It is herein reported the first occurrence of Cloudina carinata in the American continent, from the Tamengo Formation in the Porto Figueiras section (Corumbá Municipality, Mato Grosso do Sul State, Brazil). The importance of this new occurrence is the expansion of the geographic distribution of Cloudina carinata, indispensable for global correlations. Additionally, this new occurrence could collaborate to the inclusion of the South America sections in international biostratigraphic correlation and palaeobiogeographic and palaeoecological reconstructions.

\section{References}

Adôrno, R.R.; Do Carmo, D.A.; Walde, D.H.; Denezine, M.; Boggiani, P.C.; Sousa, S.C.; Vasconcelos, J.R.; Tobias, T.C.; Guimarães, E.M.; Vieira, L.C.; Figuereido, M.F.; Caminha, S.A.; Suarez, P.A.Z.; Rodriguez, C.G.V.; Pinho, D.M.; Schneider, G. \& Muyamba, R. (2017). Cloudina lucianoi (Beurlen \& Sommer, 1957), Tamengo Formation, Ediacaran, Brazil: taxonomy, analysis of stratigraphic distribution and biostratigraphy. Precambrian Research, 301: 19-35. https://doi.org/10.1016/j.precamres.2017.08.023

Cai, Y.; Hua, H.; Schiffbauer, J.D.; Sun, B. \& Yuan, X. (2013). Tube growth patterns and microbial mat-related lifestyles in the Ediacaran fossil Cloudina, Gaojiashan Lagerstätte, South China. Gondwana Research, 25, 1008-1018. https://doi.org/10.1016/j.gr.2012.12.027
Conway Morris, S.; Mattes, B.W. \& Chen, M. (1990). The early skeletal organism Cloudina: new occurrences from Oman and possibly China. American Journal of Science, 290-A: 245-260.

Cortijo, I.; Martí Mus, M.; Jensen, S. \& Palacios, T. (2010). A new species of Cloudina from the terminal Ediacaran of Spain. Precambrian Research, 176: 1-10. https://doi.org/10.1016/j.precamres.2009. 10.010

Cortijo, I.; Cai, Y.; Hua, H.; Schiffbauer, J.D. \& Xiao, S. (2015a). Life history and autecology of an Ediacaran index fossil: Development and dispersal of Cloudina. Gondwana Research, 28: 419-424. https:// doi.org/10.1016/j.gr.2014.05.001

Cortijo, I.; Mus, M.M, Jensen, S. \& Palacios, T. (2015b). Late Ediacaran skeletal body fossil assemblage from the Navalpino anticline, central Spain. Precambrian Research, 267: 186-195. https://doi.org/10.1016/j. precamres.2015.06.013

Gaucher, C.; Sial, A.N.; Poiré, D.G.; Cernuschi, F.; Ferreira, V.P.; Chiglino, L.; González, P.D.; Martínez, G \&; Pimentel, M.M. (2006). Chemostratigraphy of the Mina Verdún Group and other cement-grade Proterozoic limestone deposits in Uruguay. V South American Symposium on Isotope Geology, Short Papers, Punta del Este, pp. 250-253.

Grant, S.W.F. (1990). Shell structure and distribution of Cloudina, a potential index fossil for the terminal Proterozoic. American Journal of Science, 290-A: 261-294.

Hahn, G.; Hahn, R.; Leonardos, O.H.; Pflug, H.D. \& Walde, D.H.G. (1982). Korperlich erhaltene Scyphozoen - Reste aus dem Jungprakambrium Braziliens. Geologica et Palaeontologica, 16: 1-18.

Hofmann, H.J. \& Mountjoy, E.W. (2001). NamacalathusCloudina assemblage in Neoproterozoic Miette Group (Byng Formation), British Columbia: Canada's oldest shelly fossils. Geology, 29 (12):1091-1094. https:// doi.org/10.1130/0091-7613(2001)029<1091:NCAI $\mathrm{NM}>2.0 . \mathrm{CO} ; 2$

Hua, H.; Chen, Z.; Yuan, X.; Zhang, L. \& Xiao, S. (2005). Skeletogenesis and asexual reproduction in the earliest biomineralizing animal Cloudina. Geology, 33: 277-280. https://doi.org/10.1130/G21198.1

Kontorovich, A.E.; Varlamov, A.I.; Grazhdankin, D.V.; Karlova, G.A.; Klets, A.G.; Kontorovich, V.A.; Saraev, S.V.; Terleev, A.A.; Belyaev, S.Y.; Varaksina, I.V.; Efimov, A.S.; Kochnev, B.B.; Nagovitsin, K.E.; Postnikov, A.A. \& Filippov, Y.F. (2008). A section of Vendian in the east of the West Siberian Plate (based on data from Borehole Vostok 3). Russian Geology and Geophysics, 49: 932-939. https://oi. org/10.1016/j.rgg.2008.06.012

Sour-Tovar, F.; Hagadorn, J.W. \& Buitrón-Rubio, T. (2007). Ediacaran and Cambrian index fossils from Sonora, Mexico. Palaeontology, 50: 169-175. https:// doi.org/10.1111/j.1475-4983.2006.00619.x 
Terleev, A.A.; Postnikov, A.A.; Tokarev, D.A.; Sosnovskaya O.V. \& Bagmet, G.N. (2011). Cloudina-Namacalathus-Korilophyton association in the Vendian of Altai-Sayan Foldbelt (Siberia). Neoproterozoic sedimentary basins: stratigraphy, geodynamics and petroleum potential. Proceedings of the International conference (Novosibirsk, 30 July - 02 Aug.; 2011, Novosibirsk, 96-98.

Warren, L.V.; Fairchild, T.R.; Gaucher, C.. Boggiani, P.C.; Poiré, D.G.; Anelli, L.E. \& Inchausti, J.C.G. (2011). Corumbella and in situ Cloudina in association with thrombolites in the Ediacaran Itapucumi Group, Paraguay. Terra Nova, 23: 382-389. https:// doi.org/10.1111/j.1365-3121.2011.01023.x

Warren, L.V.; Simoes, M.G.; Fairchild, T.R.; Riccomini, C.; Gaucher, C.; Anelli, L. E, Freitas, B. T.; Boggiani, P.C. \& Quaglio, F. (2013). Origin and impact of the oldest metazoan bioclastic sediments. Geology, 41: 507-510. https://doi.org/10.1130/G33931.1

Warren, L.V.; Quaglio, F.; Riccomini, C.; Simões, M.G.; Poiré, D.G.; Strikis, N.M.; Anelli, L.E. \& Strikis, P.C. (2014). The puzzle assembled: Ediacaran guide fossil Cloudina reveals an old proto-Gondwana seaway.
Geology, 42 (5): 391-394. https://doi.org/10.1130/ G35304.1

Warren, L.V.; Quaglio, F.; Simões, M.G.; Gaucher, C.; Riccomini, C.; Poiré, D.G.; Freitas, B.T.; Paulo C.B. \& Sial A.N. (2017). Cloudina-CorumbellaNamacalathus association from the Itapucumi Group, Paraguay: Increasing ecosystem complexity and tiering at the end of the Ediacaran. Precambrian Research, 298, 79-87. https://doi.org/10.1016/j. precamres.2017.05.003

Warren, L.V.; Freitas, B.T.; Riccomini, C.; Boggiani, P.C.; Quaglio, F.; Simões, M.G.; Fairchild, T.R.; Giorgioni, M.; Gaucher, C.; Poiré, D.G.; Cáceres, A.A. \& Sial, A.N. (2019). Sedimentary evolution and tectonic setting of the Itapucumi Group, Ediacaran, northern Paraguay: From Rodinia break-up to West Gondwana amalgamation. Precambrian Research, 322: 99-121. https://doi.org/10.1016/j.precamres.2018.12.022

Zhuravlev, A.Yu.; Liñán, E.; Gámz Vintaned, J.A.; Debrenne, F. \& Fedorov, A.B. (2012). New finds of skeletal fossils in the terminal Neoproterozoic of the Siberian Platform and Spain. Acta Palaeontologica Polonica, 57: 205-224. https://doi.org/10.4202/app.2010.0074 